\title{
Nuclear Medicine Technology Progress Report for Quarter Ending June 30, 1977
}

\author{
J. K. Poggenburg
}

\section{OAK RIDGE NATIONAL LABORATORY}

OPERATED BY UNION CARBIDE CORPORATION FOR THE ENERGY RESEARCH AND DEVELOPMENT ADMINISTRATION 


\section{DISCLAIMER}

This report was prepared as an account of work sponsored by an agency of the United States Government. Neither the United States Government nor any agency Thereof, nor any of their employees, makes any warranty, express or implied, or assumes any legal liability or responsibility for the accuracy, completeness, or usefulness of any information, apparatus, product, or process disclosed, or represents that its use would not infringe privately owned rights. Reference herein to any specific commercial product, process, or service by trade name, trademark, manufacturer, or otherwise does not necessarily constitute or imply its endorsement, recommendation, or favoring by the United States Government or any agency thereof. The views and opinions of authors expressed herein do not necessarily state or reflect those of the United States Government or any agency thereof. 


\section{DISCLAIMER}

Portions of this document may be illegible in electronic image products. Images are produced from the best available original document. 
This report was prepared as an account of work sponsored by the United States Government. Neither the United States nor the Energy Research and Development Administration/United States Nuclear Regulatory Commission, nor any of their employees, nor any of their contractors, subcontractors, or their employees, makes any warranty, express or implied, or assumes any legal liability or responsibility for the accuracy, completeness or usefulness of any information, apparatus, product or process disclosed, or represents that its use would not infringe privately owned rights. 
Contract No. W-7405-eng-26

HEALTH AND. SAFETY RESEARCH DIVISION

NUCLEAR MEDICINE TECHNOLOGY PROGRESS REPORT

FOR QUARTER ENDING JUNE 30, 1977

J. K. Poggenburg

This report was prepared as an account of work

sponsored by the United States Government. Neither
the United States nor the United States Energy

Research and Development Admunistration, nor any of

their employees, nor any of their contractors,

subcontractors, or or heir employ, express of Impled, or assumes any legal

tiability or responsibility for the accuracy, completenes

ot usefulness of any information, apparatus, produet of process disclosed, or represents
infringe privately owned rights.

Work sponsored by

ERDA Division of Biomedical and Environmental Research

Date Published - September 1977

NOTICE This document contains information of a preliminary nature. It is subject to revision or correction and therefore does not represent a final report.

OAK RIDGE NATIONAL LABORA'IORY

Oak Ridge, Tennessee 37830

operated by

UNION CARBIDE CORPORATION

for the

ENERGY RESEARCH AND DEVELOPMENT ADMINISTRATION 
Previous reports in this series:

ORNL/TM-5809

ORNL/TM-5936 


\section{CONTENTS}

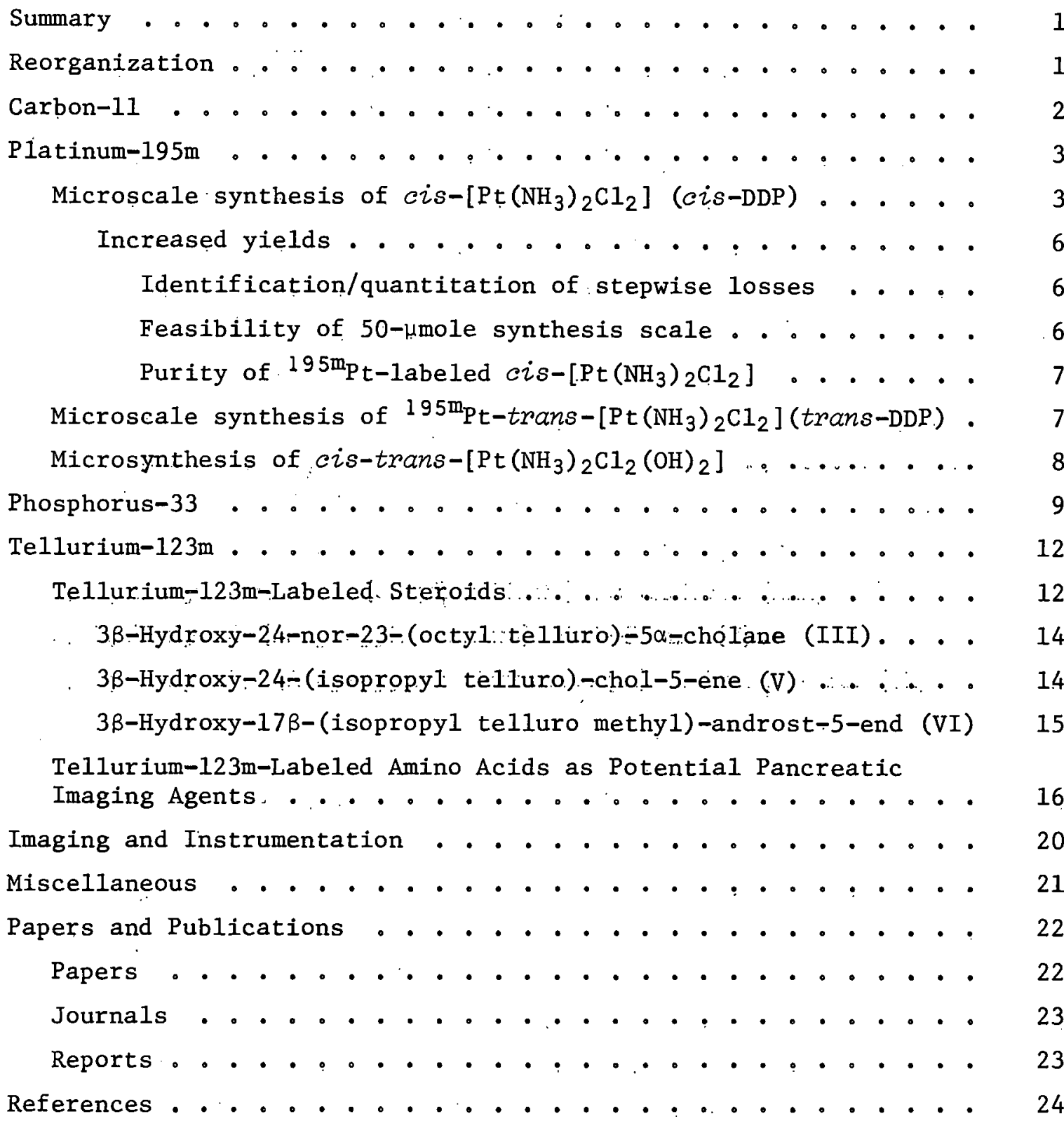


NUCLEAR MEDICINE TECHINOLOGY PROGRESS REPORT.

FQR QUARTER ENDING JUNE 3Q, 1977.

SUMMARY

Formation of the Nuclear Medicine Technology Group within the new. Health and Safety Research Division is announced. Progress 1s reported for the applications of ${ }^{11} \mathrm{C}, 195 \mathrm{~m}_{\mathrm{Pt}},{ }^{3} \mathrm{P}$, and $123 \mathrm{~m}_{\mathrm{Te}}$. of note in this report is the progress in the microscale synthesis

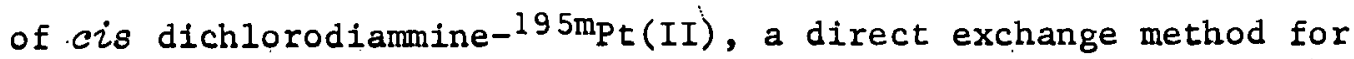
labeling $\mathrm{POCl}_{3}$ with ${ }^{3} \mathrm{P}$, and the sùccessful synthesis of a $12.3 \mathrm{~m}_{\mathrm{Te}}$-iabeled amino acid, $\mathrm{DL}-\alpha$-amino- $\gamma$-(phenyl telluro ethy 1 ) butyric acid.

\section{REORGANIZATION}

In April 1977 the Health and Safety Research Division was created from components of the former Health Physics Division, the Environmental Sciences Division, and the Operations Division. The new Division has..been organized into four sections: Biological and Radiation Physics, Chemical Physics, Technology Assessments, and Biomedical Effects and Instrumentation under which this activity is organized as Nuclear Medicine Technology. It includes the former. Blomedical Radioisotopes Program from the Operations Division and the Image Enhancement and.Medical Instrumentation Programs from the former Medical Physics and. Internal Dosimetry Section of Health Physics. The other groups in the Biomedical Effects and Instrumentation Section are: Metabolịm and Dosimetry, Health Effects and Epidemiology, and Monitoring Technology and Instrumentation.

This report series is the successor to the Biomedical Radioisotope Program reports and w11l henceforth cover the activities in medical instrumentation. 
CARBON-11

T. A. Butzer

After a protracted shutdown of the cyclotron for repairs, a proton beam was achieved in the latter part of this quarter and the synthes is and clinical testing of ${ }^{1 /} \mathrm{C}$-labeled compounds as tumor localization agents in collaboration with Oak Ridge Associated Universitles (ORAU) were resumed.

Two human patient scans were made with lic-1-aminocyciopentanecarboxylic

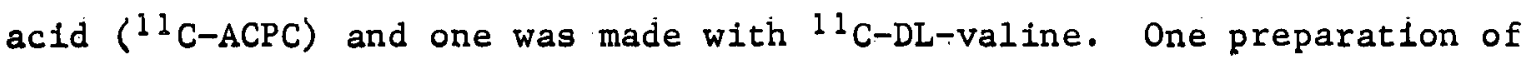
$11_{C-D L}-t r y p t o p h a n$ was made for quality assurance testing in preparation for human clinical use. The patient scans were made at ORAU using the recently installed positron tomographic instrument (ECAT). These tomographic scans were the first obtained at ORAU with ${ }^{1}{ }^{1} \mathrm{C}-1$ abeled compounds, and they are being evaluated to determine what information advantage this new technique offers over conventional scanning methods.

In preparation for the production of ${ }^{1}{ }^{1} \mathrm{C}$-labeled glucose for radiopharmaceutical use, the uptake of ${ }^{1{ }^{l} \mathrm{C}}$ in a light-starved swiss chard leaf was measured. A mixture of ${ }^{1}{ }^{1} \mathrm{CO}-1{ }^{1} \mathrm{CO}_{2}$ of undetermined composition was exposed to the leaf illuminated by light from a fluorescent tube. Approximately $350 \mathrm{mCi}$ of $1 \mathrm{l} \mathrm{C}$ was incorporated in the leaf during a 10-min exposure to the ${ }^{1}{ }^{\mathrm{C}}$ gas mixture initially containing $2500 \mathrm{mCi}$ of ${ }^{1 /} \mathrm{C}$. This qualitative experiment confirmed the suitability of the apparatus and technique for the proposed synthesis of ${ }^{11} \mathrm{C}$-glucose.

Plans for the next quarter include accelerated clinical evaluation of

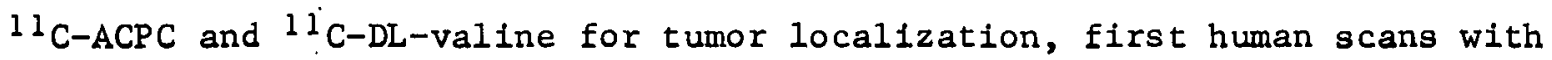
${ }^{1}{ }^{1} \mathrm{C}-\mathrm{DL}-$ tryptophan, and preclinical animal studies with ${ }^{1{ }^{1} \mathrm{C}-g l u c o s e .}$ 
PLATINUM-195m

J.. D: Hoeschele and T. A. Butler

As part of the continuing medical cooperative program to study antitumor compounds, one shipment each of $195 \mathrm{~m}_{\mathrm{Pt}}$-labeled hexachloroplatinic acid, $\mathrm{H}_{2} \mathrm{PtCl}_{6}$, and $195 \mathrm{~m}_{\mathrm{Pt}}$ labeled cis $\left[\mathrm{Pt}\left(\mathrm{NH}_{3}\right)_{2} \mathrm{Cl}_{2}\right]$, cis-DDP, was made to the University of Southern.California, and one shipment of $195 \mathrm{~m}_{\mathrm{Pt}}$-labeled [Pt(trans-l-DAC) malonate] was made to Mary Hitchcock Memorlal Hospital.

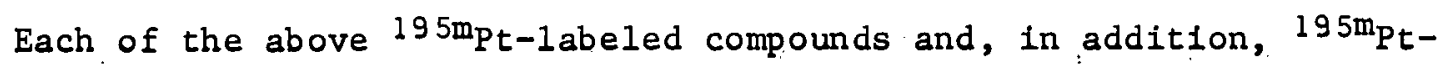
labeled trans-DDP were supplied to the ORNL Blology. Division for DNA binding studies. A collaborative effort with ORAU has been initiated for the purpose of investigating the subcellular distribution of cis-DDP.

In addition to medical cooperative activities, research efforts have centered on (a) the optimization of the microscale synthesis of ${ }^{195 m_{P t}}$ labeled cis-DDP; and (b) microscale syntheses and animal distribution studies of other key Pt(II) compounds which loom as potential second generation drugs or which may be useful in gaining Insight into the mechanism of action and the structure-activity relationships of platinum, antitumor drugs.

Microscale Synthestis of cis-[Pt $\left.\left(\mathrm{NH}_{3}\right)_{2} \mathrm{Cl}_{2}\right]$ (cis-DDP)

Optimization of the microscale synthesis of $195 \mathrm{~m}_{\mathrm{Pt}}$ is nearing completion. Completion was anticipated this quarter, but there are a few remaining experiments needed to finalize this synthesis. Emphasis during this quarter has focused on (a) Identifying and quantitating stepwise losses, (b) increasing the overall yields, (c) establishing the chemical purity of the product by spectroscopic and chromatographic techniques, and (d) demonstrating the feasibility of synthesis on a 50-umole scale.

The present microsynthesis.scheme for $195 \mathrm{~m}_{\mathrm{Pt}-c i 8-D D P}$ is illustrated in Fig. 1 below and a summary of the detalls of synthesis (scale, yields, 
losses and purity) appears in Table 1. Reference will be made to this material in the sections which follow.

1. $\mathrm{Pt}+$ aqua regia $\stackrel{\Delta}{\rightarrow} \mathrm{H}_{2} \mathrm{PtCl}_{6}$

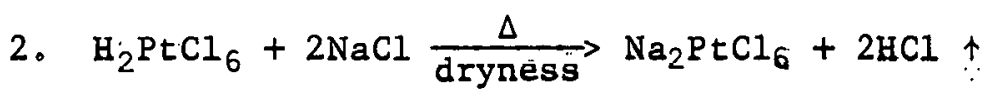

$\leq 0.5$

3. $2 \mathrm{Na}_{2} \mathrm{PtCl}_{6}+\mathrm{N}_{2} \mathrm{H}_{4} \cdot 2 \mathrm{HCl} \stackrel{5-10^{\circ} \mathrm{C}}{\longrightarrow} ; \frac{85^{\circ} \mathrm{C}}{5 \mathrm{~min}} \longrightarrow 2 \mathrm{Na}_{2} \mathrm{PtCl}_{4}+\mathrm{N}_{2}+6 \mathrm{HCl}$

4. $\mathrm{Na}_{2} \mathrm{PtCl} \mathrm{H}_{1}+\mathrm{KI}_{\mathrm{xs}} \underset{\text { amblent tèmp }}{\longrightarrow} \mathrm{K}_{2} \mathrm{Pr} \mathrm{T}_{4}+2 \mathrm{NaCl}+2 \mathrm{KCl}$

5. $\mathrm{K}_{2} \mathrm{Ptt} \mathrm{I}_{4}+.2 \mathrm{NH}_{3} \cdot \underset{\text { amblent temp }}{\longrightarrow} \operatorname{cis}-\mathrm{Pt}\left(\mathrm{NH}_{3}\right)_{2} \mathrm{I}_{2}++.2 \mathrm{KI}$

6. $\operatorname{cis}-\mathrm{Pt}\left(\mathrm{NH}_{3}\right)_{2} \mathrm{I}_{2}+2 \mathrm{AgNO}_{3} \frac{\Delta}{50-60^{\circ} \mathrm{C}}$

$$
\text { cis- }\left[\mathrm{Pt}\left(\mathrm{NH}_{3}\right)_{2}\left(\mathrm{H}_{2} \mathrm{O}\right)_{2}\right]^{2+}, 2 \mathrm{NO}_{3}{ }^{-}+.2 \mathrm{AgI}+
$$

7. $c i s-\left[\mathrm{Pt}\left(\mathrm{NH}_{3}\right)_{2}\left(\mathrm{H}_{2} \mathrm{O}\right)_{2}\right]^{2+}, 2 \mathrm{NO}_{3}^{-}+\mathrm{HCl}_{\mathrm{xs}} \overrightarrow{250^{\circ} \mathrm{C}}$.

$$
\text { eis-[ } \left.\mathrm{Ft}\left(\mathrm{NII}_{3}\right), \mathrm{Cl}_{2}\right]++2 \mathrm{HNO} 3
$$

8. Purification by recrystallization $(0.1 . N \mathrm{HCl}$ or $0.15 \mathrm{M} \mathrm{NaCl}))$

Tuliul

Fig. 1. Microscale synthesis of cle- $\left[\mathrm{Pt}\left(\mathrm{NH}_{3}\right)_{2} \mathrm{Cl}_{2}\right]$. 


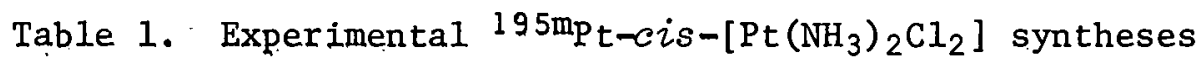

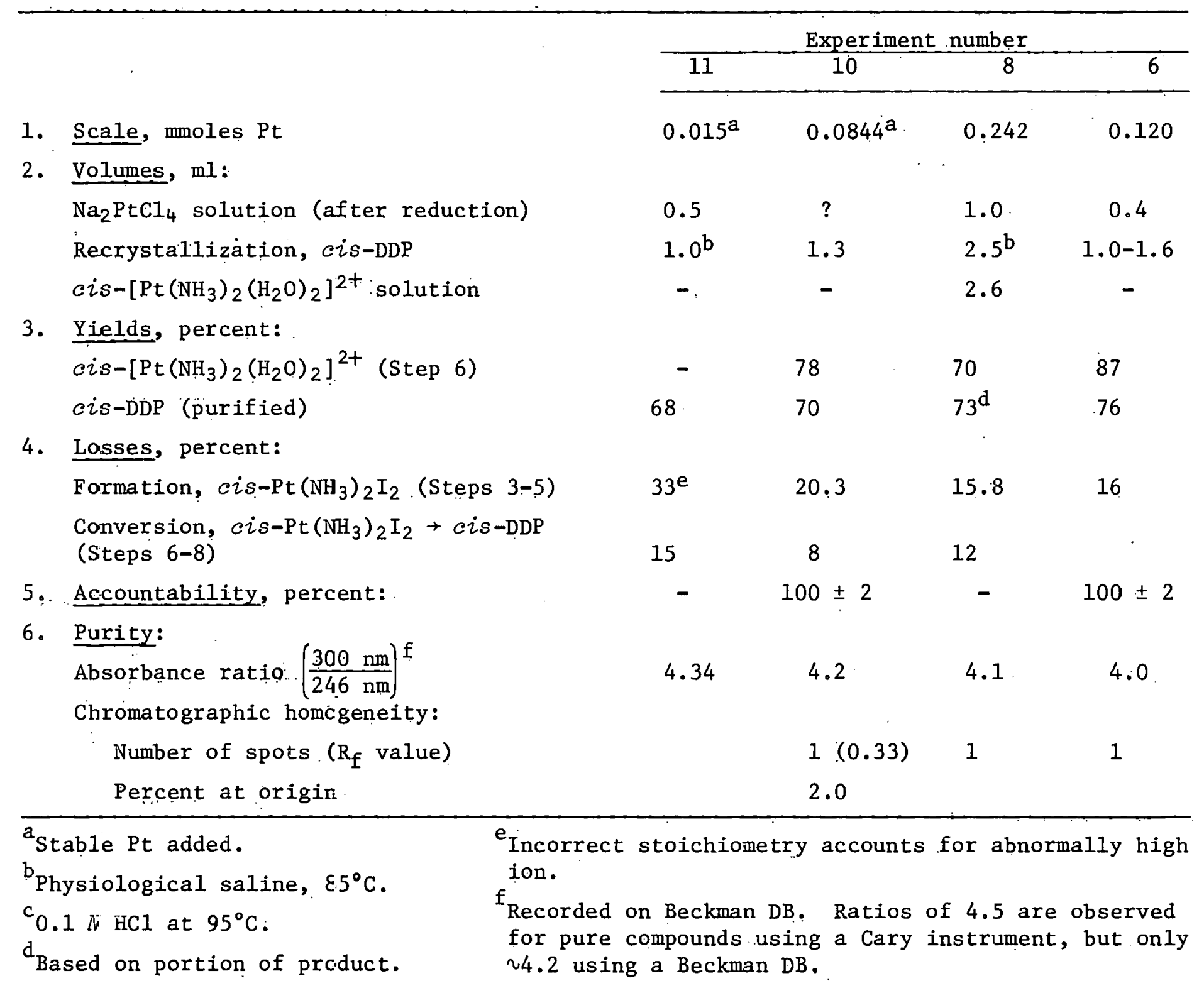


Increased yields

Yields of cis-DDP, previously in the range of $40-60 \%$, have been increased to $272 \%$ (average of four recent syntheses). The improvement in yield is principally the result of: (a) maximizing the concentrations of $\mathrm{Pt}$ (IV) and $P t(I I) ~(\geq 0.24 M)$ employed in steps 3 and 4 , respectively, and (b) general minimizing of solution volumes in all subsequent steps, particularly in the washing and recrystallization operations.

Identification/quantitation of stepwise losses. Average stepwise losses are listed in Fig. 1 and stepwise losses for the four individual experiments are listed in Table 1 . (Hot-cell processing losses are not included: In the losses considered here.) Minor losses $(\leq 0.5 \%)$ are incurred in the removal of residual $\mathrm{NO}_{3}{ }^{-}$, Introduced on dissolution of platinum in aqua regia, and in the subsequent transfer of $\mathrm{Na}_{2} \mathrm{PtCl}_{6}$ solution $(0.5-1.0 \mathrm{ml})$. to screw-capped 15-ml centrifuge tubes in which all synthetic/purification steps are performed. Presently, steps 3-5 account collectively for as much as 15-20\% 1oss; however, it appears certain that the majority of this loss occurs in step 4. Quantitation of the extent of reduction (step 3 ) by absorption spectrophotometry will pinpoint the high loss step. Optimization of this step will complete the work planned for $195 \mathrm{~m}_{\mathrm{Pt}}$-labeled cis-JDP. Conversion of cis-Pt $\left(\mathrm{NH}_{3}\right)_{2} \mathrm{I}_{2}$ to pure cis-DDP (steps 6-8). involves $21 U-1 b \%$ loss, $1 / 3$, of which results from washing and recrystalli-. zation. Minimizing losses in this part of the synthesis is critically dependent upon minimizing solution volumes. The intrinsic solubility of cis-DDP in $0.1 \mathrm{~N}$ chloride ion media contributes significantly to the losses incurred during washing and/or recrystallization. Appreciable reduction in loss at this stage might be possible if the conversion of cis- $\left[\mathrm{Pt}\left(\mathrm{NH}_{3}\right)_{2}\left(\mathrm{H}_{2} \mathrm{O}\right)_{2}\right]^{2+}$ to cis-DDP (steps 7 and 8 ) is carried out in physiological saline and the resultant saline solution is passed through (or contacted with) a mixed-bed resin 1 . the NaCl form. This procedure could eliminate both the washing and recrystallization steps.

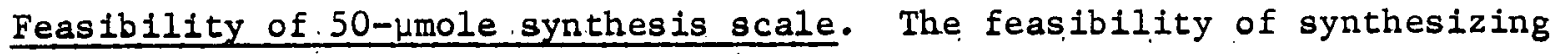
cis-DDP at the 50 mole scale has been demonstrated (cf. Table 1, synthesis. 
No. 11). Both yield (68\%) and purity of material are excellent. Consequently, it is entirely possible that the microsynthesis could be reduced further to a scale of 25 moles (or less). At this scale of synthesis it becomes practical to consider incorporating $197 \mathrm{Pt}\left(\beta, \gamma\right.$-emitter, $\mathrm{T}_{1 / 2}=$ $20 \mathrm{hr}$ ) into cis-DDP in order to prepare a high specific-activity product. The calculated specific activity of reactor-produced ${ }^{197} \mathrm{Pt}$ is considerably higher (100-200X) than 195 mpt. (1.0 mCi/mg Pt). High specific-activity ${ }^{197} \mathrm{Pt}-1$ abeled cis-DDP could have potential utility in clinical pharmacodynamic studies, therapeutic studies (radio- plus chemotherapy), and studies of tissue localization (e.g., in kidney), particularly for electron microscopy and autoradiographic (EM-ARG) techniques.

Pur1ty of $195 \mathrm{~m}_{\mathrm{Pt}-\mathrm{labeled}}$ cis-[Pt $\left.\left(\mathrm{NH}_{3}\right)_{2} \mathrm{Cl}_{2}\right]$. Platinum-195m-1abeled cis-DDP meets the well defined purity criteria established for stable cis-DDP. 1,2 Preparations exhibit major absorption maxima at 300 and $365 \mathrm{~nm}$ and an absorbance ratio $\left(\right.$ As $\left.\frac{300}{246}\right)$ of $4.2 \pm 1$. (Absorbance ratios $\geq 4.5$ are observed for pure compounds using a Cary spectrophotometer but only $\sim 4.2$ on our Beckman DB spectrophotometer.) Purity evaluations employing paper.chromotography indicate that a typical compound exhibits a single homogeneous spot with an $R_{f}$ value of $0.33-0,36$, using 2-in. Whatman 3MM paper. Eluents used were $9: 1$ acetone: $\mathrm{X}\left(\mathrm{X}-\mathrm{H}_{2} \mathrm{O}, 1 \mathrm{MHCl}\right)$ at $21^{\circ} \mathrm{C}$. Two percent of the applied compound ( $\sim \mu \mathrm{\mu g}$ total) remains at the origin for the $9: 1$ acetone: $1 M$ HCl mixture, whereas $26-8 \%$ remains when using $9: 1$ acetone: $\mathrm{H}_{2} \mathrm{O}$.

Microscale Synthesis of $\left.195 \mathrm{~m}_{\mathrm{Pt}-\text { trans- }} \mathrm{Pt}\left(\mathrm{NH}_{3}\right)_{2} \mathrm{Cl}_{2}\right]$ (trans-DDP)

A microscale synthesis ( 0.1 mmole) of trans-DDP has been developed for studies of the mechanism of action of platinum antitumor drugs in conjunction with the ORNL Biology Division.

Cis- and trans-DDP are geometrical isomers of the composition [ $\left.\mathrm{Pt}\left(\mathrm{NH}_{3}\right)_{2} \mathrm{Cl}_{2}\right]$. Whereas cis-DDP exhibits potent antitumor activity, trans-DDP exhibits no antitumor activity. This drastic difference in biological activity for structurally similar compounds has stimulated comparative investigations 
into the binding of these isomers with . DNA and precursor species. TransDDP was synthesized for use. in these studies. The two synthesis schemes examined are outlined below.

Scheme A:

(1) $\mathrm{Na}_{2} \mathrm{PtCl}_{4}+\mathrm{NH}_{4} \mathrm{OH}(\mathrm{xs}) \frac{\mathrm{ag} \cdot}{50^{\circ} \mathrm{C}}\left[\mathrm{Pt}\left(\mathrm{NH}_{3}\right)_{4}\right] \mathrm{Cl}_{2}+2 \mathrm{NaCl}$

(2) $\left[\mathrm{Pt}\left(\mathrm{NH}_{3}\right)_{4}\right] \mathrm{Cl}_{2}+\mathrm{HCl}(6 \mathrm{M}) \stackrel{\text { reflux }}{\longrightarrow} \operatorname{trans}-\left[\mathrm{Pt}\left(\mathrm{NH}_{3}\right)_{2} \mathrm{Cl}_{2}\right]+2 \mathrm{NH}_{4} \mathrm{Cl}$

Scheme B:

(1) $\quad \mathrm{cis}-\left[\mathrm{Pt}\left(\mathrm{NH}_{3}\right)_{2} \mathrm{Cl}_{2}\right]+\mathrm{NH}_{4} \mathrm{OH}(\mathrm{xs}) \frac{\mathrm{ag}}{50^{\circ} \mathrm{C}} \rightarrow\left[\mathrm{Pt}\left(\mathrm{NH}_{3}\right)_{4}\right] \mathrm{Cl}_{2}+\mathrm{NH}_{3} \uparrow$

(2) $\left[\mathrm{Pt}\left(\mathrm{NH}_{3}\right)_{4}\right] \mathrm{Cl}_{2}+\mathrm{HCl}(6 \mathrm{M}) \stackrel{\text { reflux }}{\longrightarrow} \operatorname{trans}-\left[\mathrm{Pt}\left(\mathrm{NH}_{3}\right)_{2} \mathrm{Cl}_{2}\right]+2 \mathrm{NH}_{4} \mathrm{Cl}$

Platinum-195m-1abeled cis-DDP or $\mathrm{Na}_{2} \mathrm{PtCl}_{4}$ can be used as suitable starting materials. Both are prepared as described above in the synthesis of

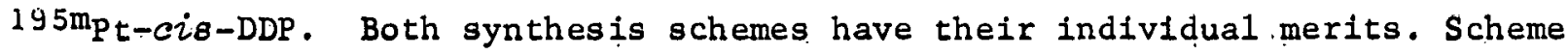
$B$ is preferred if cis-DDP is prepared at the same time, particularly since a purffled and assayed starting materlal would be available. Yields are. high in both schemes and quantitative in the case of $\mathrm{B}$.'

Microsynthesis of cis-trans-[Pt $\left.\left(\mathrm{NH}_{3}\right)_{2} \mathrm{Cl}_{2}(\mathrm{OH})_{2}\right]$

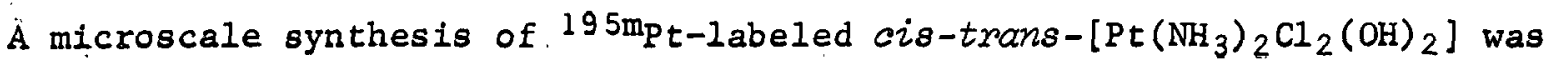
developed for in-house uptake-distribution studies and testing of the premise that this compound may derive its antitumor activity by virtue of a stereo-specific reduction in vivo to active cis-DDP. The distribution data w1ll be presented in the next progress report.

This compound can be considered to be the parent of a family of Pt(IV) antitumor drugs having the general formula cis-trans- $\left\lfloor\mathrm{PtA}_{2} \mathrm{Cl}_{2}(\mathrm{OH})_{2}\right\rfloor$ ( $A=\mathrm{NH}_{3}$, amines). These compounds are sufficiently soluble to be administered Intravenously, exhibit reasonable therapeutic indices (5-12), 
and appear to offer some promise as clinical alternatives to cis-DDP, particularly the analogs $\mathrm{A}=\mathrm{NH}_{3}$, isopropylamine, and cyclopentylamine. The microscale synthesis was, adapted from that reported for the analog [Pt en $\mathrm{Cl}_{2}(\mathrm{OH})_{2}$ ]. The synthesis scheme is as follows:

$$
\text { cis-Pt }\left(\mathrm{NH}_{3}\right)_{2} \mathrm{Cl}_{2}+\mathrm{H}_{2} \mathrm{O}_{2} \frac{(30 \%)}{\text { warm }}>\text { cis-trons }
$$

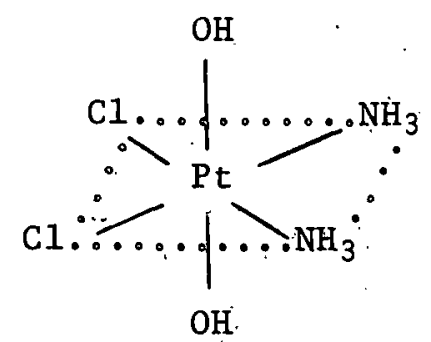

1. 1 milliliter of $30 \% \mathrm{H}_{2} \mathrm{O}_{2}$ plus a small volume of water $(0.5 \mathrm{ml}$ ) was added to solid $195 \mathrm{~m}_{\mathrm{Pt}-c i 8-D D P}(12.3 \mathrm{mg})$ and then the mixture was warmed. The slurry gradually transformed into a clear pale yellow solution, and no.crystallization of product occurred on cooling to $0^{\circ} \mathrm{C}$.

2. $37.6 \mathrm{mg}$ stable cis-DDP. was added plus additional $\mathrm{H}_{2} \mathrm{O}_{2}$ (30\%), and the olurry was warmed. Cis-trans $\left[\mathrm{Pt}\left(\mathrm{NH}_{3}\right)_{2} \mathrm{Cl}_{2}(\mathrm{OH})_{2}\right]$ began to crystallize out soon.after the stable cis-DDP dissolved.

3. The product : was washed twice with water.

PHOSPHORUS - 33

D. V. Woo

The inert atmosphere glove box is now operational. Although the auxiliary cooling for removal of furnace heat from the oynthesis of labeled ${ }^{3}{ }^{3} \mathrm{PCl}_{3}$ has not yet been Installed; the box can be used for the handing of oxygen-sensitive and/or radioactive compounds.

Efforts to optimize the microscale synthesis of ${ }^{3} \mathrm{p}$-labeled cyclophosphamide continued during this quarter. The labeled alkylating agent will be tested for synergistic radiotoxic and cytotoxic activity. Initial syntheses of labeled compound resulted in very low radlochemical aid 
chemical yields $(<5 \%)$. Major losses in radiochemical yield occurred during initial incorporation of the ${ }^{33} \mathrm{P}-1$ abel from ${ }^{3}{ }^{3} \mathrm{POCl}_{3}$. Losses in chemical yield occurred during the last.stage of the synthes is in the reaction of bis(2-chloroethyl)phosphoramide dichloride with 3-amino-1propanol in the presence of triethylamine. The choice of reaction solvent was found to be important during the last step of this reaction. The use of dichloromethane resulted, in a significant amount of the bis(2-chloroethyl)amine being produced, Indicating that acid hydrolysis was occurring between the phosphorus-uitrogen bond. 'lhis results trom the partial solvation of the triethylamine hydrochloride salt generated within the reaction solvent, Substituting the solvent p-dioxane alleviates this problem because the triethylamine salts formed will precipitate from solution. The change of reaction solvents led to the decision to isolate and purify the intermediate bis (2-chloroethyl) phosphoramide dichloride by chromatography procedures described previously in order to prevent possible side products from interfering with the final reaction. Further experimental syntheses with unlabeled material by this approach have resulted in a significant improvement in chemical yields.

Various techniques were evaluated for the synthesis of radiolabeled $3{ }^{3} \mathrm{POCl}_{3}$. Initially the reaction of $\mathrm{PCl}_{5}$ with $\mathrm{P}_{2} \mathrm{O}_{5}$ in an Inert solvent appeared favorable, but further studies resulted in variabie chemical yields with a. maximum yield of $30 \%$ (assayed by infrared spectrophotometry). Although this procedure is considered entirely feasible as a method analogous to the synthesis of ${ }^{33} \mathrm{PCl}_{3}$ via a ${ }^{33} \mathrm{PCl}_{5}$ intermediate, it was decided to test methods for the direct conversion of labeled starting material (aqueous $\mathrm{H}_{3}{ }^{3} \mathrm{PO}_{4}$ ) to ${ }_{3}{ }^{\mathrm{POCl}_{3}}$ with a minimum of reaction steps. One such procedure evaluated involved the direct interaction of $\mathrm{H}_{3}{ }^{3}{ }^{3} \mathrm{PO}_{4}$ and $\mathrm{H}_{2} \mathrm{O}$ with $\mathrm{PCl}_{5}$ to produce labeled ${ }^{3}{ }^{3} \mathrm{POCl}_{3}$ in carrier $\mathrm{POCl}_{3}$ by the reactions:

1. $\mathrm{H}_{3}{ }^{3} \mathrm{PO}_{4}+3 \mathrm{PCl}_{5}+{ }^{3}{ }^{3} \mathrm{POCl}_{3}+3 \mathrm{POCl}_{3}+3 \mathrm{HCl}$

2. $\mathrm{H}_{2} \mathrm{O}+\mathrm{PCl}_{5} \rightarrow \mathrm{POCl}_{3}+2 \mathrm{HCl}$ 
The experimental procedure consisted of the following:

a. Lyophilization of an aqueous solution contalning carrier-free $\mathrm{H}_{3}{ }^{33} \mathrm{PO}_{4}$ plus a known amount of $\mathrm{H}_{3} \mathrm{PO}_{4}$ carrier to a small volume $(0.1 \mathrm{ml})$.

b. Careful addition of $\mathrm{PCl}_{5}$ (during an alternating freeze-thaw cycle of the lyophilized solution) based on the molar quantity of $\mathrm{H}_{3} \mathrm{PO}_{4}$ carrier and the $\mathrm{H}_{2} \mathrm{O}$ remaining after lyophilization.

c. Vacuum distillation of the $\mathrm{POCl}_{3}$.

Experimental runs using carrier-free $\mathrm{H}_{3} 3{ }^{3} \mathrm{PO}_{4}$ without added carrier $\mathrm{H}_{3} \mathrm{PO}_{4}$ resulted in $<1 \%$ incorporation of the radiolabel. Addition of carrier Improved the radiochemical yield slightly (5\%). Increasing the reaction time from 4 to $16 \mathrm{hr}$ after addition of the calculated amount of $\mathrm{PCl}_{5}$ further improved yields to $331 \%$. Poor radiochemical yields were mainly attributed to the relative rates of reaction for equations.(1) and (2) above. The selective hydrolysis of $\mathrm{PCl}_{5}(\mathrm{Eq} .2$ ) appears to be the preferred reaction which proceeds at a much faster rate, thereby producing unlabeled $\mathrm{POCl}_{3}$, rather than the labeled product. The number of experimental manipulations (lyophilization, addition of $\mathrm{PCl}_{5}$, and vacuum distillation), however, was judged to be a serious disadvartage.

A more promising procedure thus far is a direct exchange reaction. This synthesis depends upon an apparent exchange of OH radicals in carrierfree $\mathrm{H}_{3} \mathrm{PO}_{4}$ with $\mathrm{Cl}$ atoms on the $\mathrm{POCl}_{3}$ carrier via an undetermined intermediate species. The carrier-free $\mathrm{H}_{3}{ }^{3}{ }^{3} \mathrm{PO}_{4}$ is initially evaporated on the Interior of a glass ampul by vacuum distillation. A known quantity of POCl $_{3}$ is transferred to the ampul, and the ampul is sealed under vacuum with a torch. The glass ampul is then placed.in a screw-top stainless steel cylinder which is heated in an oven at $\sim 220^{\circ} \mathrm{C}$, for 4 days. Upon being opened, the ampul is placed into a specially designed apparatus, and the $\mathrm{POCl}_{3}$ is vacuum distilled into an appropriate receiver ampul. Experimental runs starting with $500 \mu \mathrm{Cl}$ of carrier-free $\mathrm{H}_{3}{ }^{3} \mathrm{PO}_{4}$ and $167 \mathrm{mg}$ of $\mathrm{POCl}_{3}$ have resulted in. 75\% labeling efficiency. 
Plans during the forthcoming quarter are to optimize all reaction conditions to improve radiochemical yields in, the synthesis of ${ }^{3} \mathrm{p}$-labeled $\mathrm{POCl}_{3}$ and cyclophosphamide.

TELLURIUM-123m

F. F. Knapp and K. R. Ambrose

I'ellurium-123m-Labeled serorolde

Studies were, continued concerning the effect of structural modifications. of teliuro steroids on the ability of rat adrenals to concentrate the $123 \mathrm{~m}_{\mathrm{Te}}$-labeled compounds in vivo. One new telluro sterold has been prepared in which the tellurium molety is present in a shortened sidechain (VI, Fig. 2). In this analog the 17B-sidechain is shorter (i.e., 17Bisopropyl telluro methyl) compared to our original $123 \mathrm{~m}_{\mathrm{Te}}$-labeled adrenal agent (I) in which the 17B-sidechain is considerably larger (17B-isopropyl telluro isobuty 1 ). This new analog was prepared by a route analogous to that used to prepare 3B-hydroxy-24-(1sopropy $\perp$ telluro)-chol-j-ene (V'). A commercial sample of etienic acid methyl ester (methyl-3ß-hydroxy-17Bcarboxyl-androst-5-en-oate) was converted to the corresponding $3 \beta$-methy 1 . ether which was. then reduced with a metal hydride to yield 3B-methuxy-17B(hydroxy methyl)-androst-5-ene. Treatment with triphenyl phosphonium dibromlde generated from triphenyl phosphine and carbon tetrabromide gave

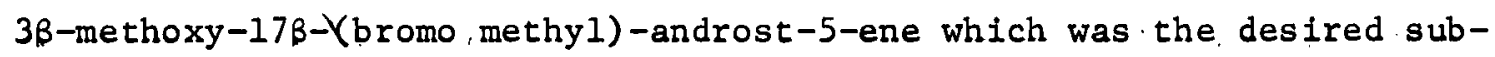
strate for coupling with sodium isopropy 1 . tellurol. The latter reaction

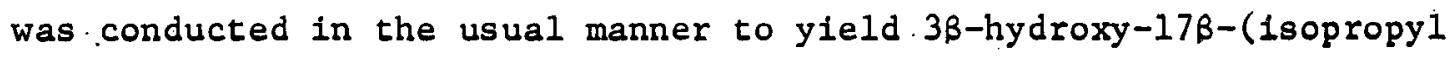
telluro methyl)-androst-5-ene (VII) which was purified and fully character1zed. The ${ }^{\prime 2} \mathrm{3m}_{\mathrm{m}} \mathrm{Te}-\mathrm{lab}$ led analog was prepared by the same methods. The results of tissue distribution experiments and rectilinear.scanning studies using $123 \mathrm{~m}_{\mathrm{Te}}$-labeled (VI) are discussed below. In addition, discussions of similar studies using several of the other telluro steroid analogs that were begun in the last Quarterly Report are completed below. 

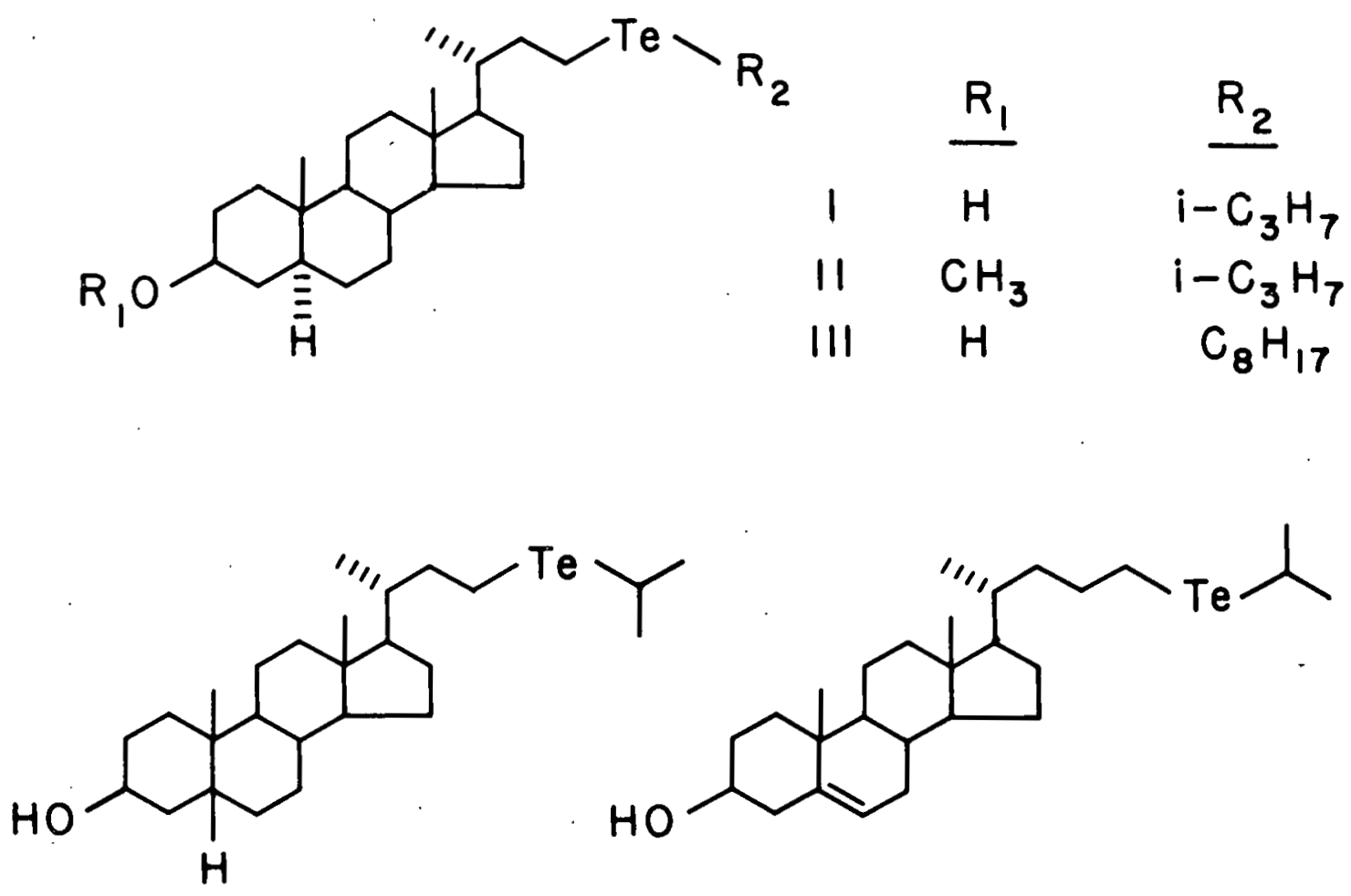

IV

V<smiles>CC(C)[Te]CC1CCC2C3CC=C4CC(O)CCC4(C)C3CCC12C</smiles>

\section{VI}

Fig. 2. The Structure of Several New Steroids Containing the Tellurium Heteroatoin in the $\mathrm{C}-17$ Sidechain. 


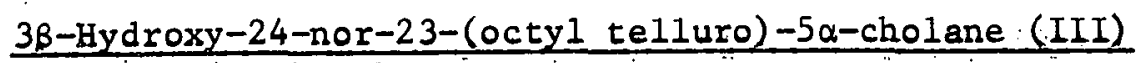

Tissue distribution studies using $123 \mathrm{~m}_{\mathrm{Te}}$-labeled (III) indicated that intravenous administration resulted in slow accumulation of radioactivity in rat adrenals. Seven days after injection, the adrenal/tissue ratios were similar to ratios obtained one day after administration of $123 \mathrm{~m}_{\mathrm{Te}}$ labeled 3B-hydroxy-24-nor-23-(isopropyl telluro)-5a-cholane. (I). These. results were corroborated by rectilinear scans of rats injected with : $123^{\mathrm{m}_{\mathrm{Te}}}$-labeled (III) and indicate that this agent would not be effective for early adrenal visualization.

$3 \beta-$ Hydroxy-24-(1sopropy 1 telluro) -cho1-5-ene (V)

The rectilinear scans of both male and female rats following injection of $123 \mathrm{~m}_{\mathrm{Te}}$-labeled (V) indicated very rapld adrenal concentration of radioactivity. The results of tissue distribution experiments correlated well.with the rectilinear scan data, indicating a high concentration of radioactivity in the adrenals and also the ovaries of female rats. Since $.123 \mathrm{~m}_{\mathrm{Te}}$-labeled (I) and (V) are the only two analogs we have found that show a high adrenal uptake, a comparative study was performed to determine the relative adrenal uptake of these two agents in both male and female rats. The results of these studies (Table 2) indicate that $123 \mathrm{~m}_{\mathrm{Te}}$-labeled (V) concentrates somewhat better in rat adrenals. Because this analog is . much less expensive to prepare than (I) these data would suggest that $123 \mathrm{~m}_{\mathrm{Te}}$-labeled (V) should be used for extensive studies in larger animals. (vide infra). 
Table 2. Adrenal/tissue ratios of $\%$ dose/g following intravenous administration of the ${ }^{123 \mathrm{~m}} \mathrm{Te}-1$ abeled steroids ${ }^{a}$.

\begin{tabular}{|c|c|c|c|c|c|}
\hline \multirow[b]{2}{*}{ Compound } & \multicolumn{2}{|c|}{ Females } & \multirow[t]{2}{*}{$\therefore$} & \multicolumn{2}{|c|}{ Males } \\
\hline & $I$ & $\mathrm{~V}$ & & $I$ & $\mathrm{~V}$ \\
\hline & \multicolumn{5}{|c|}{ Day 1} \\
\hline \multirow{5}{*}{$\begin{array}{l}\text { Blood, } \\
\text { Liver } \\
\text { Ovaries } \\
\text { Kidneys } \\
\text { Lungs }\end{array}$} & 55.7 & 63.7 & r & 49.3 & 39.5 \\
\hline & $\begin{array}{r}39.0 \\
5.3\end{array}$ & 36.3 & & $\begin{array}{l}34.1 \\
-\end{array}$ & $\begin{array}{c}19.8 \\
-\end{array}$ \\
\hline & $\begin{array}{r}5.3 \\
42.7\end{array}$ & $\begin{array}{r}7.0 \\
69.6\end{array}$ & & 30.5 & $3 \overline{9} .9$ \\
\hline & 24.7 & 23.2 & & 19.4 & 13.4 \\
\hline & \multicolumn{5}{|c|}{ Day 7} \\
\hline Blood & 129.7 & 182.5 & & 59.4 & 125.8 \\
\hline Liver & 127.5 & 133.1 & & 61.7 & 60.9 \\
\hline Ovaries & 9.4 & 6.7 & & - & - \\
\hline Kidneys & 50.6 & 72.0 & & 19.6 & 40.7 \\
\hline Lungs & 141.1 & 79.8 & & 60.8 & 43.8 \\
\hline
\end{tabular}

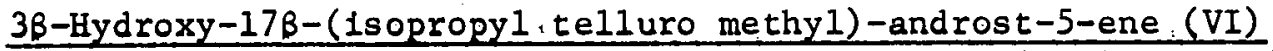

The chemical synthesis of (VI) has been described earlier in this report. Tissue distribution experiments with $123 \mathrm{~m}_{\mathrm{Te}}$-labeled (VI) have demonstrated a very low adrenali and ovarian uptake of radioactivity. It is interesting to note that seven days after injection of the labeled sterold the mafority of the radioactivity accumulated in the adipose tissue. In. fact, after seven days the concentration of radioactivity in the adipose was greater than that in the adrenals and ovaries. It is not clear.wat these results mean, and they may suggest in vivo instability of the labeled sterofd. The rectilinear scan data were similar to the tissue distribution results and indicated that there was no tissue-specific localization of this analog.

In summary, we have now essentially completed our preliminary studies involving a new class of neutral steroids labeled in the sidechain.with the ${ }^{123 \mathrm{~m}_{\mathrm{Te}}}$ nuclide (Fig. 2). These studies have defined certain struc- 
tural features that determine the ability of rat adrenals to concentrate these substances in vivo. Although none of these analogs have been found to concentrate in rat adrenals more effectively than (I) it has been demonstrated that the uptake of (V) is very similar. Using both $123 \mathrm{~m}_{\mathrm{Te}}-$ labeled (I) and (V), clear images of both the adrenal glands and the ovaries of rats have been obtained using both a rectilinear scanner and an RC type proportional counter. More recently, the adrenal glands of rabbits have.successfully been imaged using a rectilinear scanner and a gamma camera. In addition, the tissue distribution of radiodclivily lu a dog following injection of $123 \mathrm{~m}_{\mathrm{Te}}$-Iabeled ( $\mathrm{I}$ ) . indicated high adrenal/tissue ratios after nine days (1.e., adrenal/1iver ratio $=29: 1$ ). In the next quarter we will continue these studies in dogs using both $123 \mathrm{~m}_{\mathrm{Te}}$-labeled (I) and (V), and we will also attempt to image dog adrenals using several different instrumental techniques. Our success in imaging rat and rabbit adrenals suggests clinical trials in humans and, therefore, animal toxicity studies should be undertaken. The $123 \mathrm{~m}$ Te-labeled (V) appears to concentrate marginally better than. (I) in rat adrenals (Table 2), and more importantly, it is prepared from a less expensive steroid substrate. Consequently, a large-scale synthesis of (V) was recently initiated for toxicity cests in laboratory animals. Its gross toxicity will be determined in test animals, and also, histopathological examination will be conducted using the adrenal glands and other organs isolated from animals treaced with large duses of. (V).

\section{Tellurium- $123 \mathrm{~m}$-Labeled Amino Acids as Potential Pancreatic Imaging Agents}

Considerable effort has been devoted toward developing techniques for the chemical synthesis of $123 \mathrm{~m}$ Te-iabeled amino acids. Telluro amino acids have not been previously prepared and these compounds are of interest as potential pancreatic imaging agents. The early diagnosis of pancreatitis and pancreatic carcinoma is a common clinical problem. The use of ${ }^{75} \mathrm{Se}-1 \mathrm{abeled}$ selenomethionine (V.b., Fig. 3) was originally developed because of the biological. importance of methionine and the availability of the gammaemitting ${ }^{75}$ Se nuclide. Furthermore, ${ }^{75}$ Se was readily incorporated into 

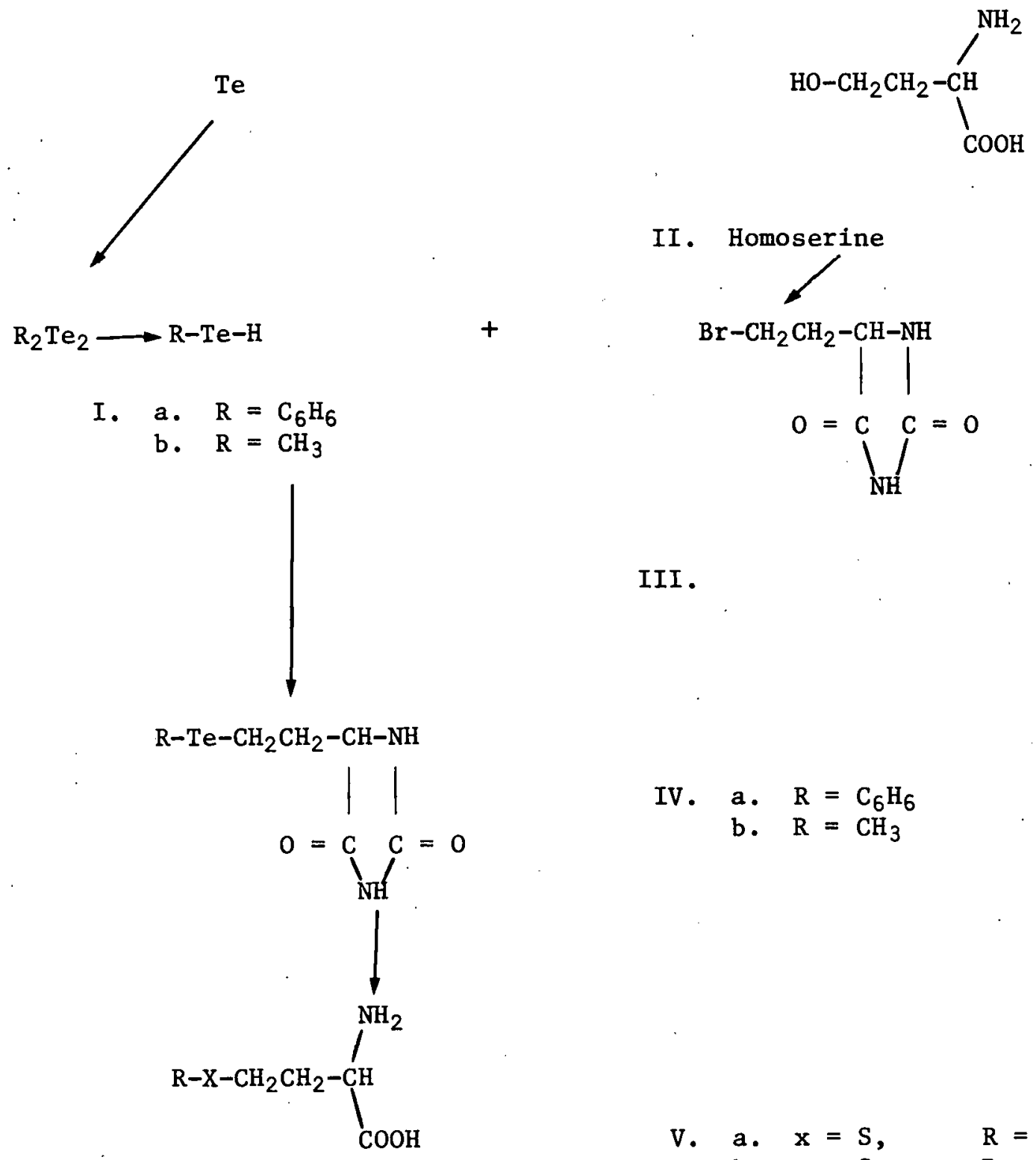

II. Homoserine

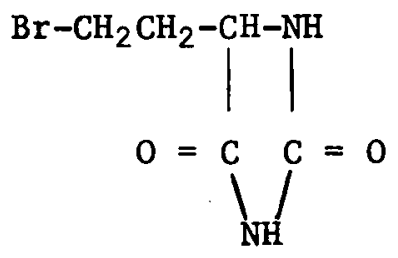

III.

IV. a. $\mathrm{R}=\mathrm{C}_{6} \mathrm{H}_{6}$

b. $\mathrm{R}=\mathrm{CH}_{3}$

$\begin{array}{ll}\text { a. } x=S, & \mathrm{R}=\mathrm{CH}_{3} \\ \text { b. } \mathrm{x}=\mathrm{Se}, & \mathrm{R}=\mathrm{CH}_{3} \\ \text { c. } \mathrm{x}=\mathrm{Te}, & \mathrm{R}=\mathrm{CH}_{3} \\ \text { d. } \mathrm{x}=\mathrm{Te}, & \mathrm{R}=\mathrm{C}_{6} \mathrm{H}_{6} \\ \text { e. } \mathrm{x}=123 \mathrm{~m}_{\mathrm{Te}}, & \mathrm{R}=\mathrm{C}_{6} \mathrm{H}_{6}\end{array}$

Fig. 3. The Synthesis of Telluro Amino Acids. 
selenomethionine by both microbiological and chemical methods. Selenomethionine ( $\left.V_{\circ} b_{0}\right)$ behaves similarly to methionine $\left(V_{\circ} a_{0}\right)$ in vivo and is concentrated in a number of animal species by the pancreas and other tissues that are involved in active protein synthesis. The multiple high-energy gamma emissions of ${ }^{75} \mathrm{Se}$, however, result in poor 1mages with an unnecessary radiation dose to the patient. To alleviate these disadvantages the use of $123 \mathrm{~m}_{\mathrm{Te}}$-labeled telluromethionine (V.e.) has been suggested as a superfor altemative for pancreatic imaging. Attempts to prepare ${ }^{123 m_{T e}} \mathrm{Tabeled}$ telluromethionine by microbiological tachniques have been unsuccessful. Our successful experience with the preparation of the $123 \mathrm{~m}$ Te-labeled steroids prompted further exploration of the synthee lo of tellurn amino acids.

Our first attempts to prepare telluro amino acids by methods involving the introduction of the benzyl telluro moiety were unsuccessful. The fallure is due primarily to the extreme instability of dibenzyl ditelluride. In addition, the benzyl:methylene carbon-tellurium bond is unstable even in simple benzyl alkyl tellurides. These properties preclude the preparation of the requisice bencyl Lellusu intermediates which perve ae eubstrates for the du Vigneaud reduction and subsequent transformation to the desired methyltelluro products. These combined facts dictated devising an alternative strategy. Our early studies of factors affecting the formation and stability of ditellurides and tellurides proved that phenyl akyl tellurldes are much more stable than simple dialkyl tellurides because of the stabilizing effect of the aromatic ring. Thus a scheme was devised for the preparation of a representative $\alpha$-amino acid containing the phenyl telluro molety (Fig. 3). The method developed should be of general applicability for the synthesis of a variety of telluro amino acids. Its. success results from strictly avoiding any attempts to isolate the tellurul intermediates. Such intermediates (I) are quite useful synthetically when generated in situ; however, and are formed by reduction of the precursor ditellurides under an inert atmosphere. For the preparation of a model telluro amino acid, diphenyl ditelluride was reduced with sodium borohydride in methanol under an argon atmosphere. The resulting phenyl tellurol was then coupled with 5-(bromoethy.1) hydantoin. (III). which was 
conveniently prepared by known methods from DL-homoserine (II). The reaction resulted in a high yleld of 5-(phenyl telluro ethyl)-hydantoin (IV.a.). This unusually substituted hydantoin is stable when stored in the dark as a solld at $4^{\circ} \mathrm{C}$. It was fully characterized and exhibited the expected physical and chemical properties. Treatment of this hydantoin with $1 \mathrm{~N}$ $\mathrm{NaOH}$ in a teflon-lined bomb at $160^{\circ} \mathrm{Cresulted}$ in hydrolysis to DL-a-amino$\gamma$-(phenyl telluro) butyric acid (V.d.). Although some decomposition was detected, the product was isolated in reasonable yield and was fully characterized by the usual methods. The $123 \mathrm{~m}_{\mathrm{Te}}-1 \mathrm{abeled}$ amino acid (V。e。) was prepared from reactor-produced $123 \mathrm{~m}_{\mathrm{Te}}$. The microscale synthes is of, diphenyl ditelluride was accomplished by reaction of the $123 \mathrm{~m}_{\mathrm{Te}}$ with phenyl magneslum chloride. The $123 \mathrm{~m}_{\mathrm{Te}}-1 \mathrm{abeled}$ diphenyl.ditelluride was. then reduced, coupled with the hydantoin, and the labeled butyric acid $\left(V, e_{0}\right)$ then obtalned by the methods described above. The physical properties of the labeled amino acid were indentical to those determined for the unlabeled product, and radloçhemical, homegeneity was established chromatographlcally. The tissue distributions of the labeled amino acid are. presently under investigation using Fischer strain rats.

Using this same methodology we are now attempting to synthesize telluro-. methionine $\left(V . c_{0}\right)$. Special precautions must be taken in this case because of the high volatility of dimethyl ditelluride and methyl tellurol (I.b.). In addition, the 5-(methyl telluro ethyl) hydantoin.(IV.b.) must be isolated

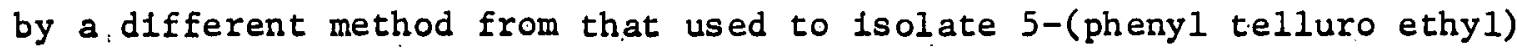
hydantoln (IV.a.). Dimethyl ditelluride has been prepared by reaction of methyl lodide with sodium ditelluride. Reduction of the ditelluride to methyl tellurol with subsequent coupling with 5-(bromo ethyl) hydantoin (III) then gave (IV.ob.). The 5-(methyl telluro ethyl) hydantoin.has been purified and characterized. The best conditions for hydrolysis of this, Intermediate to telluromethione (.$c_{.}$) must now be determined.

In summary, the methodology has now been developed for the preparation of telluro amino acids. The first such compound, DL- $\alpha$-amino- $\gamma-$ (phenyl. telluro ethyl) butyric ac1d, has been prepared. The synthesis is easily adapted to the microscale and, providling the requisite halo-alkyl 
hydantoin Intermediates are available, the preparation of a variety of telluro amino acids is possible.

During the next quarter it is anticipated that several of the required. hydantoins will be prepared and their coupling with phenyl tellurol and other tellurols will be studied in detail. The tissue distribution of any new telluro amino acids prepared will be studied by making the $123 \mathrm{~m}_{\mathrm{Te}}$ labeled analog.

IMAGING AND INSTRUMENTATION

$$
\text { F. R. BezZ. }
$$

The conversion of the Oak Ridge Imaging System (ORIS) programs from the PDP-8 to the PDP-11 language has begun using a borrowed PDP-11 computer. Since inception of ORIS, the 16-bit word has become the standard in nuclear medicine imaging systems. In order to make our developments. avallable for clinical evaluation, the conversion to the clinically used PDP-11 has been undertaken. A considerable part of the matrix convolution program, whlch is used both for antiscatter and antipenetration calculations and for the two-dimensional polynomlal least squares smoothing and bounding, has been translated. The procurement of a floppy disk drive has made possible accelerated progress in adapting the $0 S / 8$ input/output methods to the RT-11 monitor used with the PDP-11. A few of the many undocumented procedures necessary for successful use of RT-11 have been located.

An RK8E disk pack containing an ORIS system and source files has been prepared for Dr. Vavid Schurr of the Kalser. Permanente Medieal Group at Oakland, California, in response to a request through the Biomedical Computing Technology Information Center. This will provide a complete system, after minor additions or modifications to suit thelr hardware.

The success of the two-dimensional least-squares matrix method for data smoothing has encouraged us to begin development of a three-dimensional 
analagous method, two-space dimensions, and time for smoothing and bounding of dynamic sequences. The data are so sparse in dynamic sequence that every effort is needed to improve the reliability of the results. The matrix array w111 have 343 elements and thus the direct method may need. speeding up by three orthogonal two-dimensional fits.

\section{MISCELLANEOUS}

Two shipments of ${ }^{64} \mathrm{Cu}$ were supplied to ORAU to study the tissue distribution of high specific-activity ${ }^{64} \mathrm{Cu}$ citrate and ${ }^{64} \mathrm{Cu}$ bleomycin in tumored rats. Copper -64 is a positron emltter. (19\%) and may have potential. as a positron tomographic agent for detection of cancer.

Two shipments of ${ }^{18} \mathrm{~F}$ as $\mathrm{Na}^{18} \mathrm{~F}$-were made to ORAU for use in animal studies using the ECAT scanner.

High specific-activity ${ }^{141} \mathrm{CeCl}_{3}$ was made by. the nuclear reaction

$$
{ }^{139} \mathrm{La}(\mathrm{n}, \gamma){ }^{140} \mathrm{La}(\mathrm{n}, \gamma){ }^{141} \mathrm{La} \stackrel{\beta^{-}}{\longrightarrow} 141 \mathrm{Ce}
$$

and purifled by HDEHP. solvent extraction. The preparation will be tested in a cooperative study with Dr. Nathaniel Revis of the Biology. Division to measure myocardlal uptake in connection with infarct studies in a rat model. Cerlum-141 was chosen because of its imaging properties.

Nine shipments of ${ }^{43} \mathrm{~K}$ were made this quarter. Four shipments to University of Mississippl were used for radiolsotope lmaging in heart disease studies in comparison with $201 \mathrm{Tl}$ : Three shipments to Brookhaven National Laboratory were used in their studies of exchangeable electrolytes in human subjects. Two shipments to City College of New York were used for imaging studies.

Visitors this perlod 1nclude: Dr. John. Bevin, from Proctor and Gamble Malml.Valley Laboratory, to discuss their results on.toxiclty studies with ${ }^{33}$ P-labeled EHDP; Dr. Archie Prestako, Bristol Laboratories, to discuss the availability of $195 \mathrm{~m}_{\mathrm{Pt}-1 \mathrm{abeled}}$ compounds; and Dr. Charles Weems, a 
reproductive endocrinologist from the Division of Agriculture of Arlzona State University, who wanted to discuss possible radioisotopic Imaging techniques for monitoring changes in blood flow to ovaries as a function of administration of various prostaglandins. Dr. Philip DeSimone and John Butts of the V. A. Hospital, Lexington, Kentucky, and Dr. Jack Coupal, radiopharmacist, and Richard Yanzey, radiopharmacy graduate student, from the University of Kentucky visited along with Dr. Stephen Krauss, University of Tennessee Memorlal.Research Center and Hospital, to discuss possible clinical research with platinum chemutherapy compoundo. Dr. Krauss is actively testing cis-DDP in human clinical,trials. The Kentucky group also spent another session in the laboratory reviewing the synthesis of QiomDDF.

K. R. Ambrose, F. F. Knapp, and J. K: Poggenburg attended the Annual Meeting of the Society of Nuclear Medicine in Chicago, June 20-23, where two papers were presented by the Group.

PAPERS AND PUBLICATIONS

Papers

F. F. Knapp, Jr., and Kathleen R. Ambrose, "Tellurium-123m Labeled 24-Nor-23-(Isopropy1 Tellura)-5a-Gholan-3B-ol: . A New Potential Adrenal Imaging Agent," 24th Annual Meeting of the Society of Nuclear Medicine, Chicago, June 20-23, 19.77 .

F.F. Knapp, Jr., and A. P. Callahan, "l'he syncheș1s of Tellus lum-123m Labeled Steroids," 24th Annual Meeting of the Society of Nuclear Medicine, Chicago, June 20-23, 1977.

G. A. Andrews, K. F. Hübner, L. C. Washburn, B. W. Wleland, W. D. C1bbe, R. L. Hayes, T. A. Butler, and I. R. Collman, "Clinical Studies of C--11Labeled Amino Acids," poster session at the 24th Annual. Meeting of the Society of Nuclear.Medicine, Chicago, June 20-23, 1977. 
Journals

F. F. Knapp, Jr., and Kathleen R. Ambrose, "Tellurium-123m Labeled 24-Nor-

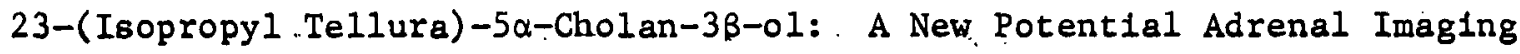
Agent," J. Nucl. Med. 18(6), 600 (1977).

F. F. Knapp, Jr., and A. P. Callahan, "The Synthesis of Tellurium-123m Labeled Stero1ds, "J. Nucl. Med. 18(6), 610 (1977).

G. A. Andrews, K. F. Hübner, L. C. Washburn, B. W. Wielyand, W. D. Gibbs; R. L. Hayes; T: A. Butler, and I. R. Collman, "Clinical, Studies of C-11labeled Amino Ac1ds," J. Nucl. Med. 18(6), 638 (1977).

F. F. Knapp, Jr., and G. J. Schroepfer, "Mass Spectrometry of Sterols: Electron Ionization Induced Fragmentation of C-4 Alkylated Cholesterols," Chem. Phys. Lipids, 17(4), 466-500 (1976).

Reports

J. K. Poggenburg, Biomedical Radiolsotope Program Progress Report for Quarter Ending March 31; 1977, ORNL/TM-5936 (June 1977). 


\section{REFERENCES}

1. National Cancer Institute Purchase Specifications for cis-[Pt $\left.\left(\mathrm{NH}_{3}\right)_{2} \mathrm{Cl}_{2}\right]$.

2. J. D. Hoeschele, unpublished work; and Clinical Brochure for cisDichlorodiammineplatinum (II), NSC-119875 (Aug. 1974).

3. F. Basolo, et al., J. Am. Chem. Soc., 72, 2433 (1950). 


\section{INTERNAL DISTRIBUTION}

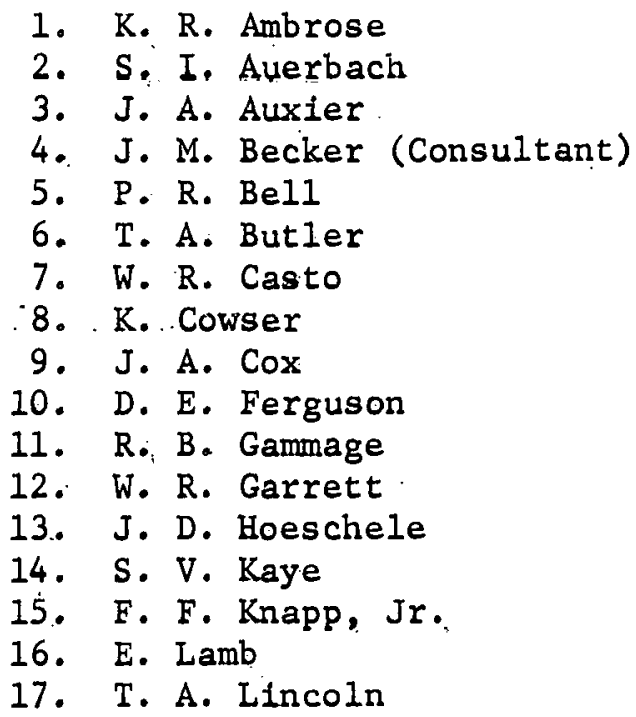

\author{
18. P. Nettesheim \\ 19. C. H. Nowlin \\ 20. C. L. Ottinger \\ 21. C. H. Patrick \\ 22-26. J. K. Poggenburg \\ 27. H. Postma \\ 28. M. E. Ramsey \\ 29. C. R. Richmond \\ 30. A. F. Rupp (Consultant) \\ 31. M. R. Skidmore \\ 32. M. J. Skinner. \\ 33. J. B., Storer \\ 34. D. V. Woo \\ 35. H. A. Wright \\ 36-37. Central Research Library \\ 38. Document Reference Section \\ 39-40. Laboratory Records Department \\ 41. Laboratory Records, ORNL RC
}

\section{EXTERNAL DISTRIBUTION}

42-43. Technical Information Center, ERDA, Oak Ridge, TN 37830

44. D. C. Davis, ERDA-ORO, Oak Ridge, TN 37830

45. J. A. Lenhard, ERDA-ORO, Oak Ridge, TN 37830

46. J. N: Maddox, ERDA-DBER, Washington, DC 20545

47. W. H. Weyzen, ERDA-DBER, Washington, DC 20545

48. R. W. Wood, Jr., ERDA-DBER, Washington, DC 20545

49. T. F. Budinger, M.D., Donner Lab., LBL, Berkeley, CA 94720

50. R. L. Hayes, ORAU, Oak Ridge, TN 37830

51. C. C. Lushbaugh, ORAU, Oak RIdge, TN 37830

52. H. A. O'Brien, LASL, Los Alamos; NM 87545

53. P. Richards, BNL, Upton, NY 11973

54. Harold L. Atkins, M.D., BNL, Upton, NY 11973

55. A. P. Wolf, BNL, Upton, NY 11973

56. H. E. Walburg, CARL, Oak Ridge, TN 37830

57. A. Solomon; M.D., UT-MRCH, Knoxville, TN 37920

58. A. Legendre, M.D., UT-School of Veterinary Medicine, Knoxville, IN :37920

59. John Venditti, National Cancer Institute, Silver Springs, MD 20910

60. S. James Adelsteln, Shields Warren Radiation Lab., Boston, MA 02115

61. David E. Kuh1, UCLA, Lab, of Nuclear Medicine, Los Angeles, CA 90024

62. John, S. Laughlin, Sloan-Kettering Inst. for Cancer, Research, NY, NY 10021

63. Paul Harper, M.D., Franklin McLean Memorial Research Institute, Chicago, IL 60637

64. Walter Wolf, University of Southern Calffornia, Los Angeles, CA 90033

65. Philip A. DeSimone, M.D., V. A. Hospital, Lexington, KY 40507

66. John Hollifield, Vanderbilt University Hospital, Nashville, TN 37232

67. Bertrand Brill, M.D., Vanderbilt University Hospital, Nashville, TN 37232 